\title{
SILENCING OF G-PROTEIN $\alpha$-SUBUNIT IN BARLEY (Hordeum vulgare L.) BY VIGS AND ITS EFFECT ON THE PLANT GROWTH
}

\author{
Muhammad Qasim SHAHID ${ }^{1,2}$, Cuneyt UCARLI ${ }^{2}$, Elif KARLIK ${ }^{2}$, \\ Semian Karaer UZUNER ${ }^{2}$, Filiz GUREL ${ }^{2,3 *}$ \\ ${ }^{1}$ South China Agricultural University, College of Agriculture, Guangzhou, CHINA \\ ${ }^{2}$ Istanbul University, Department of Molecular Biology and Genetics, Vezneciler, Istanbul, TURKEY \\ ${ }^{3}$ Istanbul University, Research and Application Center for Genetic Engineering and Biotechnology, \\ Vezneciler, Istanbul, TURKEY \\ *Corresponding author: filiz@istanbul.edu.tr
}

Received: 03.03.2015

\begin{abstract}
G-proteins play important roles in a number of cellular and developmental processes in plants. In this study, we have cloned a 317-bp fragment encoding a part of barley $G$ protein $\alpha$-subunit into $\gamma$-genome of barley stripe mosaic virus (BSMV). Barley seedlings were inoculated with this construct denoted as pSL038-1/G $\alpha$ at 3-leaf stage, and assayed for their growth, leaf area and membrane ion leakage. Silencing was achieved after 2 weeks of inoculation and confirmed by the decrease in G $\alpha$ subunit mRNAs in barley leaves. There was a significant decrease in plant growth in terms of plant height and leaf area following the viral infection. Leaf area in silenced plants were decreased by $>10 \%$ compared to control plants (wild-type or inoculated by BSMV-PDS constructs). In conclusion, silencing resulted in etiolated phenotypes and growth retardation. Our optimized VIGS protocol in barley could be adopted to evaluate extensive physiological parameters and molecular changes in $\mathbf{G} \alpha$ silenced plants.
\end{abstract}

Keywords: BSMV, G-proteins, Ion Leakage, Phytoene desaturase (PDS), Virus induced gene silencing (VIGS).

\section{INTRODUCTION}

The recent advances in functional genomics have provided abundant plant genome information. Traditional approaches for determining functions of genes, including random mutation, T-DNA insertion mutations and chemical mutagenesis have been extensively used for knockdown gene expression in plants. However, mutation approaches complicates gene function studies in nonmodel individuals due to complex genetic background, low transformation efficiency and their large genome size (Cakir et al., 2010; Huang et al., 2012). Virus-induced gene silencing (VIGS), on the other hand, is a useful and efficient approach for plant loss-of-function evaluation that can overcome the above-mentioned complications and permits knockdown of genes-of-interest and phenotypic observations within 3 to 4 weeks. VIGS allow stable RNA interference (RNAi) in plant cells and can also be performed in the species that are difficult to transform (Burch-Smith et al., 2004; Scofield and Nelson, 2009; Cakir et al., 2010). Recently, the plants in which VIGS has been used were increased considerably, and more than 30 viruses have been reported to have great prospective as VIGS vectors (Yuan et al., 2011). Barley stripe mosaic virus (BSMV) has been applied for cereal crops and is a positive-sense RNA virus with a wide- ranging hosts (Holzberg et al., 2002; Tai et al., 2005; Hu et al., 2009; Jackson et al., 2009; Meng et al., 2009). Silencing of PDS (Phytoene desaturase), an enzyme required for the biosynthesis of carotenoid pigments, can be observed as white streaks on plant leaves (Holzberg et al., 2002)

Heterotrimeric $\mathrm{G}$ proteins, also called as guanine nucleotide-binding proteins, are a family of proteins required for transduction of external signals into cellular responses (Assmann, 2002). $\mathrm{G}$ protein complexes consist of alpha $(\alpha)$, beta $(\beta)$ and gamma $(\gamma)$ subunits (Hurowitz et al., 2000; Assmann, 2002) and encoded by less numbers of genes in plants compared to mammals. In Arabidopsis, there is one gene (GPAl) encoding G-Protein $\alpha$ subunit, one gene $(A G B 1)$ encoding the G-Protein $\beta$ subunit, and at least three genes ( $A G G 1, A G G 2$ and $A G G 3)$ encoding the G-Protein $\gamma$ subunits (Chakravorty et al., 2011). Mutations in heterotrimeric $G$ proteins are not lethal and proved that those were having roles in almost all developmental stages in Arabidopsis (Perfus-Barbeoch et al., 2004). Similarly, functional studies revealed that $\mathrm{G}$ proteins are associated with germination, development, stomatal opening, phytohormone and stress responses (Ullah et al., 2001; Pandey and Assmann, 2004; Joo et al., 2005; Pandey et al. 2006; Wang et al., 2007; Fan et al., 2008; Zhang et al., 
2008). For example, both $\mathrm{G} \alpha$ and $\mathrm{G} \beta$ subunits were found to be related to stomatal aperture that controls water status and photosynthesis (Zhang et al., 2008; Nadeau, 2009). Their associations with stomatal movements were determined by using electrophysiological and pharmacological methods (Wang et al., 2011). ABA prevents stomatal opening and stimulates stomatal closure, reducing water loss through transpiration. Therefore, the role of heterotrimeric G-proteins in the opening/closing of stomata may be through the ABA signaling ( $\mathrm{Wu}$ and Assmann, 1994). The $\mathrm{G} \alpha$ subunit also regulates cell division and development: the $\mathrm{G} \alpha$ mutants caused reduction in cell division in the leaf-length (Ullah et al., 2001; Bommert et al., 2013). The Ga-null alleles produced stunted seedlings in maize, rice and Arabidopsis (Ullah et al., 2001; Bommert et al., 2013; Urano et al., 2014). Mutations in heterotrimeric G-protein had a significant effect on phenotypic plasticity for yield related traits in Arabidopsis (Nilson and Assmann, 2010).

In rice, single genes encode $\mathrm{G} \alpha$ and $\mathrm{G} \beta$, while at least five genes encode $\mathrm{G} \gamma$ subunits and one of them is involved in seed size (Huang et al., 2009). G $\alpha$ and G $\beta$ subunits are also associated with pathogenic response and tolerance to salinity (Colaneri et al., 2014). So far, efficiency of a VIGS-based silencing of G-proteins was not tested in barley which is an important model cereal from Poaceae family. Therefore, the objective of this study was to investigate the possibility of production of knockout barley plants for $\mathrm{G} \alpha$ subunit and analyze the effects of gene silencing on growth conditions and membrane ion leakage. For this purpose, we first cloned a part of barley $\mathrm{G}$ protein $\alpha$-subunit and successfully cloned the fragment into the BSMV vector $\gamma$-genome. Silencing was followed by phenotypic changes and confirmed by RT-PCR analysis.

\section{MATERIALS AND METHODS}

\section{Plant material}

Hordeum vulgare L. cv. Tokak157/37 (Tokak) seeds were kindly provided by Aegean Agricultural Research Institute and re-propagated from field-grown plants. Seeds were planted in the pots with $190 \mathrm{~mm}$ diameter and grown under controlled growth chambers (Angeloantoni ECHL) at $20-25{ }^{\circ} \mathrm{C}$ with a $14 / 10 \mathrm{~h}$ light $\left(\sim 75 \mu \mathrm{mol} / \mathrm{m}^{2} \mathrm{~s}\right) /$ dark photoperiod. Relative humidity of growth chamber was kept at 50-65\%.

\section{Construction of BSMV vectors for silencing experiments}

Plasmids containing the tripartite BSMV genomes $\alpha, \beta$ and $\gamma$ were kindly provided by Dr. Steven R. Scofield (Purdue University). Barley G-protein $\alpha$ subunit mRNA sequence (NCBI, AF267485.2) was used to design the primers by IDT PrimerQuest program (Table 1).

Table 1. Primer sequences used in the study

\begin{tabular}{lllr}
\hline Gene & Study & Primer sequences $\mathbf{5} \rightarrow \mathbf{3}$ ' & Amplicon size (bp) \\
\hline \multirow{2}{*}{$G \alpha$} & Cloning to pSL038-1 & AAAGGCGGCCGCGCACATCCACAAG & 317 \\
& & CCTGTACGAGTTCTTAATTAAGGAG & 632 \\
\multirow{2}{*}{$\alpha$} & RT-PCR & AGCTTGCCCAAGTGGAACTA & \\
\multirow{2}{*}{$\alpha-T U B$} & \multirow{2}{*}{ RT-PCR } & CTCGCACACAGTCAAAGGAA & 676 \\
\hline
\end{tabular}

Newly designed primers consists of the Not I and PacI restriction sites for further cloning to pSL038-1 vector which is $\gamma$ genome of BSMV vector system. Total RNA was isolated from barley leaves with the TRIZOL $\AA$ reagent (Invitrogen) and treated with DNase I (Fermentas) in a final volume of $100 \mu \mathrm{l}$. First strand cDNA synthesis was performed using $4 \mu \mathrm{g}$ of total RNA, $100 \mathrm{U}$ of SuperScriptII RT (Invitrogen) and $1 \mu \mathrm{g}$ of Oligo (dT) $)_{20}$ primer according to the manufacturer's instructions in a final volume of $40 \mu \mathrm{l}$. Using previously described primers, a specific fragment of 317-bp was amplified by PCR and cloned into $\mathrm{pCR} 8 / \mathrm{GW} / \mathrm{TOPO}$ vector (Invitrogen, $\mathrm{K} 250020)$. BSMV- $\gamma$ vector (pSL038-1) was isolated from E. coli DH5 $\alpha$ cells which were grown in LB media including $50 \mathrm{mg} / \mathrm{L}$ ampicillin. After digestion of pSL0381 with $N o t \mathrm{I} / P a c \mathrm{I}$, fragment was ligated to the vector by T4 DNA ligase (Takara 20115). Vector-insert construct was confirmed by restriction enzyme analysis on agarose gel and denoted as pSL038-1/G $\alpha$ (Figure 1). We have used BSMV- $\gamma$ RNA with 185-bp fragment from barley PDS gene (denoted as BSMV-PDS) which cause a photo- bleaching phenotype as positive control in silencing experiments. Wild-type plants were kept as control.

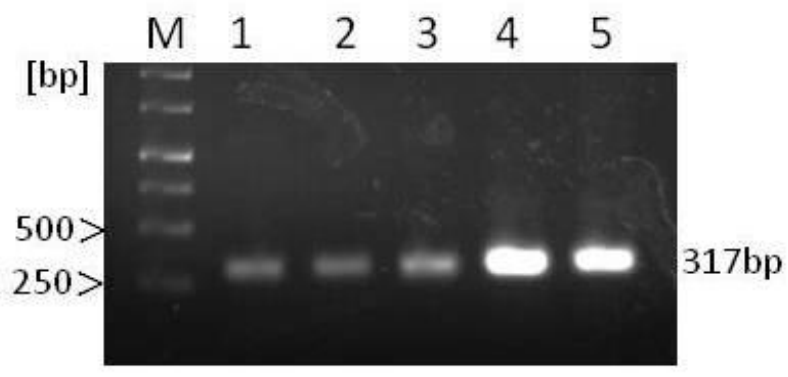

Figure 1. Cloning of a 317-bp insert corresponding to G- $\alpha$ barley subunit into BSMV- $\gamma$ vector confirmed by PCR. M: DNA Ladder, 1-5: colonies carrying pSL038-1/G $\alpha$ construct

\section{In vitro transcription of BSMV vectors}

The procedures for linearization of plasmids and in vitro transcription of viral RNAs were performed as described by Scofield et al. (2005). Complete linearization was checked via separation of $1 \mu$ product on $1 \% \mathrm{w} / \mathrm{v}$ 
agarose gel. Then linearized plasmid reaction was treated with RNase inhibitor before in vitro transcription step. Linearized DNAs of each vector $(\alpha, \beta, \gamma)$ were used as a template for the synthesis of RNAs. Ambion mMessage mMachine T7 (Cat No:1344) Kit was used for in vitro transcriptions with following procedure. From each genome a transcription reaction mix was prepared in volumes of $2.5 \mu \mathrm{l}$. Each reaction mix contained $0.75 \mu \mathrm{l}(80$ ng) of template DNA, $0.25 \mu \mathrm{l}$ Buffer (10x), $1.25 \mu \mathrm{l}$ of NTP-mix $(2 x)$ and $0.25 \mu$ lof enzyme mix. Mixture was incubated at $37^{\circ} \mathrm{C}$ for 2 hours. $1 \mu$ of DNase was added to tubes and kept at $37^{\circ} \mathrm{C}$ for 15 minutes. Then $30 \mu \mathrm{l}$ nuclease-free water and $30 \mu \mathrm{LiCl}(7.5 \mathrm{M})$ were added to tubes. The tubes were placed at $-20^{\circ} \mathrm{C}$ for $1 \mathrm{~h}$ to precipitate the RNAs and then centrifuged at $4^{\circ} \mathrm{C}, 15,000$ rpm for 15 minutes. Supernatant was discarded and pellet was washed with $70 \%$ ethanol. Pellets were dried at RT (room temperature) and dissolved by $2.5 \mu$ nuclease-free water. The quality and quantity of RNAs were measured by $1 \%$ agarose gel and Nanodrop 2000 (Thermo Scientific, USA)

\section{Inoculation of barley plants with BSMV construct}

Plants were infected with BSMV construct using a modified protocol (Holzberg et al., 2002). One $\mu$ l of each of the in vitro transcription reactions for $\alpha, \beta$ and $\gamma$ RNAs were mixed and added to $20 \mu \mathrm{l}$ of FES buffer $(0.1 \mathrm{~m}$ glycine, $1 \% \mathrm{w} / \mathrm{v}$ sodium pyrophosphate, $0.06 \mathrm{~m} \mathrm{~K}_{2} \mathrm{HPO}_{4}$, $1 \% \mathrm{w} / \mathrm{v}$ celite, $1 \% \mathrm{w} / \mathrm{v}$ bentonite, $\mathrm{pH} 8.5)$. This solution was then applied to plants by rub inoculation method. The solution was pipetted on the leaf between the thumb and a first finger of the hand and the leaf was gently pressed with first finger and thumb. The whole upper part of leaf was coated with this solution by sliding the gently pinched fingers throughout whole leaf and this process was repeated twice.

\section{Plant growth assessments and ion leakage}

Plant growth was considered by plant height and leaf size. The measurement of plant height was performed daily after inoculation during 20 days using a ruler from the base of the plant to top of the leaf. Plant height was given as the average growth $(\mathrm{mm})$. The leaf sizes of the $2^{\text {nd }}$ leaf of barley plants were calculated according to the following formula as "leaf size $=$ length $\times$ width $\times 0.7$ " (Jamaux et al., 1997). These calculations were performed continuously for 20 days after the inoculation of BSMV, using the fully expanded $2^{\text {nd }}$ leaf from the top. Membrane ion leakage was measured by the following procedure: Five leaf pieces from each plant were sampled and placed in glass tubes. The pieces were then washed with distilled water for three times, capped and placed in a thermostatically controlled chamber maintained at $25^{\circ} \mathrm{C}$ in the dark. After 16 hours, $60 \mu \mathrm{l}$ of the sample were used for conductivity measurement (E1) by HORIBA conductivity meter B-137. The tubes were then autoclaved at $121^{\circ} \mathrm{C}$ for
20 min and samples were again analyzed with the conductivity meter for E2 values. Ion leakage was calculated and presented as "E1 / E2 x 100".

\section{$R N A$ extraction and $R T-P C R$}

Total RNA was extracted from leaves using the TRIZOL $\AA$ reagent (Invitrogen) by a protocol as given by the manufacturer. The RNA concentration was quantified with a NanoDrop ND-1000 spectrophotometer. Primer pairs for RT-PCR analyses were designed using NCBI Primer-BLAST program and given in Table 1. Alphatubuline $(\alpha-T U B)$ was used as a reference gene to amplify a 676-bp fragment. RT-PCR was performed in $50 \mu \mathrm{l}$ volume, with $25 \mathrm{mM} \mathrm{MgCl} 2,10 \mathrm{mM}$ dNTP, $0.8 \mathrm{U}$ RNase inhibitor, 5U AMV RTase XL, 5U AMV-Optimized Taq DNA polymerase (Promega) and $1 \mu \mathrm{M}$ each of forward and reverse primers in $1 \times$ One Step RNA PCR Buffer (AccessQuick RT-PCR System, Promega). PCR profile was as follow: $50^{\circ} \mathrm{C}$ for 30 minutes for reverse transcription and $94^{\circ} \mathrm{C}$ for 2 minutes for initial denaturation then 30 cycles at $94^{\circ} \mathrm{C}$ for $30 \mathrm{~s}$, annealing at $60^{\circ} \mathrm{C}$ for $60 \mathrm{~s}$ and $72^{\circ} \mathrm{C}$ for $45 \mathrm{~s}$, final extension at $72^{\circ} \mathrm{C}$ for 10 minutes. The amplified samples were then analyzed on $1 \%$ agarose gel.

\section{Statistical analyses}

The data were analyzed by SPSS software version 21 (Chicago, IL, USA) using analysis of variance (ANOVA). Significance of differences between treatment means was calculated by Tukey's HSD test. P value less than 0.05 is considered as statistically significant.

\section{RESULTS AND DISCUSSION}

\section{Gene silencing in barley seedlings}

The plants were grown in pots under controlled growth conditions (See Materials and Methods) in three independent biological replicates and pSL038-1/G $\alpha$ was applied to plants at 3-4 leaf stage for silencing of $\mathrm{G} \alpha$ subunit. Barley leaves depicted photo-bleaching symptoms typical for PDS silencing within $7 \mathrm{~d}$ after inoculation (Figure 2A). Inoculated plants showed stunted growth compared with control plants. Photobleaching started from the upper part of the leaf, especially in tips, and later on white narrow streaks spread along the veins of whole leaf in inoculated plants. Similar photobleaching symptoms were reported in previous studies (Holzberg et al., 2002; Ma et al., 2012). Etiolated leaves were also observed three weeks after inoculations by pSL038-1/G $\alpha$.

RT-PCR was carried out to confirm the visual virus induced gene silencing. No band was observed in silenced plants after 2 and 3 weeks, while control seedlings produced a clear band of 632-bp of Ga subunit (Figure 2B). BSMV-PDS inoculated plants also showed the presence of $\mathrm{G} \alpha$ subunit fragment (Figure $2 \mathrm{~B}$ ). 

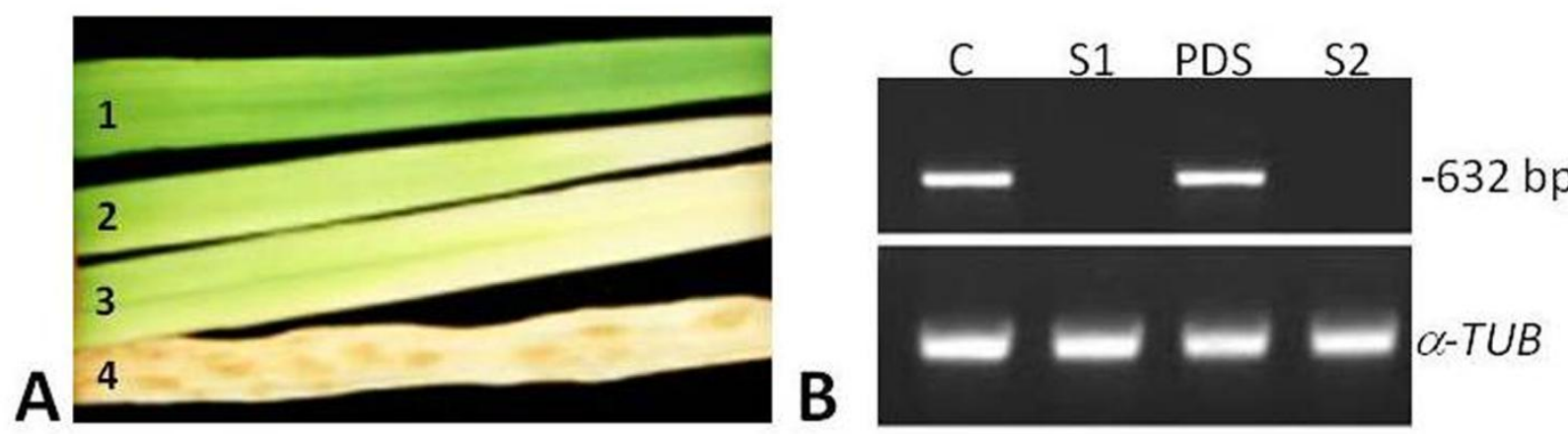

Figure 2. (A) Different phenotypes of barley leave from control (1); BSMV-PDS (2); pSL038-1/G $\alpha$ inoculated leaf after 5 days (3) and after 3 weeks (4). (B) RT-PCR analysis of pSL038-1/G $\alpha$ silenced plants. C: Control, S1: silenced plant after 2 weeks, PDS: plant inoculated by BSMV-PDS, S2: silenced plant after 3 weeks, lower panel is alpha-tubuline $(a-T U B)$ as reference gene

\section{Effect of silencing on plant growth and physiology}

There was a decrease in the plant growth after the inoculation of pSL038-1/G $\alpha$ construct. The plants inoculated with pSL038-1/G $\alpha$ construct showed significantly lower plant heights than BSMV-PDS and control plants (Figure 3). Silenced plants also showed reduction in leaf area compared to control plants (Figure 4). Our results depicted that there was more than $10 \%$ decrease in leaf area of silenced plants with pSL038-1/Go, $20 \mathrm{~d}$ after inoculation. Overall, the growth was not totally suppressed but decreased compared to control plants.

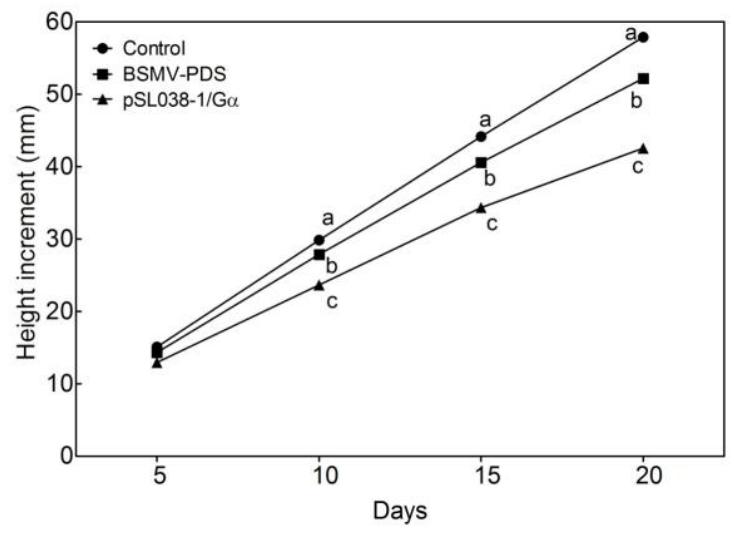

Figure 3. Effect of pSL038-1/G $\alpha$ inoculation on plant height. Plant height of 12 plants were measured $(n=3)$ each day after the inoculation. BSMV-PDS: plants inoculated with phytoene desaturase (PDS) construct. Different letters indicate significant differences $(P \leq 0.05)$ between treatments according to Tukey's HSD test.

Ion leakage was between 25.27 and 26.47 in control and test plants at the beginning of inoculation (0 day) (Table 2). After 10 days of inoculation with BSMV constructs, all infected plants showed slightly higher ion leakage (Table 2) while control plants maintained their values after 10 or 20 days. Ion leakage values between control and $\mathrm{G} \alpha$ silenced plants were 43.20 and 79.73 after 10 and 20 days, respectively. Ion leakage in BSMV-PDS inoculated plants was also increased slightly. As ion leakage is an important indication of membrane injury and frequently occurred in the stressed cells (Babu et al., 2004; Kocheva et al., 2014; Faralli et al., 2015); this parameter should be studied more detailed. In addition, pleitropic effects in $\mathrm{G} \alpha$ silenced plants should be considered due to central roles of G-proteins in many cellular pathways in the cell.

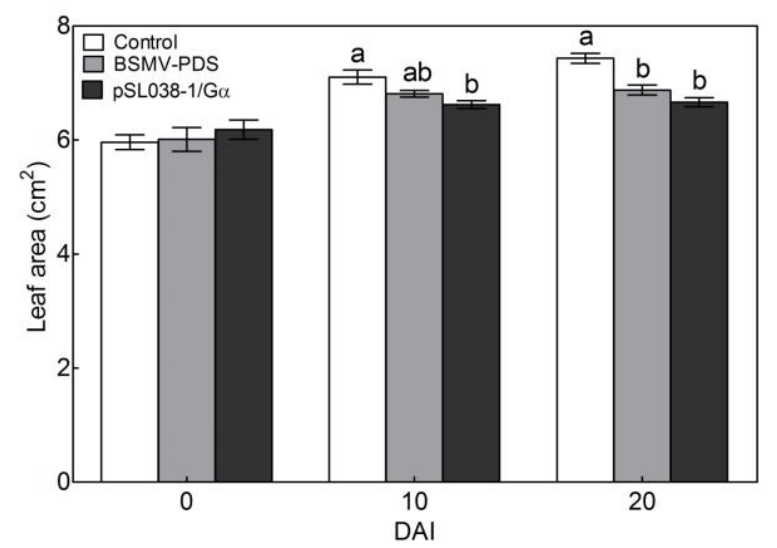

Figure 4. Effect of silencing of Ga subunit on leaf area. Leaf area was measured from the first day to $20^{\text {th }}$ day after inoculation. C: Control; BSMV-PDS: inoculated with phytoene desaturase (PDS) construct; pSL038-1/G $\alpha: G \alpha$ silenced plants. Different letters indicate significant differences $(P \leq 0.05)$ between treatments according to Tukey's HSD test. 
Table 2. Ion leakage in barley leaves of plants inoculated with BSMV-PDS and pSL038-1/G $\alpha$ after 0, 10 and 20 days. Data represent mean values of three biological replicates with \pm SD.

\begin{tabular}{lccc}
\hline & 0 day & 10 Dai $^{\mathbf{a}}$ & 20 Dai \\
\hline Control & $25.27 \pm 0.97$ & $27.60 \pm 0.59 \mathrm{c}$ & $26.52 \pm 0.78 \mathrm{c}$ \\
BSMV-PDS & $26.43 \pm 0.78$ & $36.10 \pm 0.65 \mathrm{~b}$ & $51.87 \pm 1.04 \mathrm{~b}$ \\
pSL038-1/G $\boldsymbol{a}$ & $26.47 \pm 0.46$ & $43.20 \pm 1.38 \mathrm{a}$ & $79.73 \pm 0.50 \mathrm{a}$ \\
\hline
\end{tabular}

${ }^{\text {a }}$ Days after inoculation. Different letters indicate significant differences $(P \leq 0.05)$ between treatments according to Tukey's HSD test.

BSMV-VIGS vectors provide an effective and reliable tool for plant functional genomics research as shown in various monocot species (Burch-Smith et al., 2004; Scofield and Nelson, 2009; Cakir et al., 2010; Pacak et al., 2010; Ma et al., 2012). Notably, we found complete silencing of pSL038-1/G $\alpha$ two weeks after inoculation in barley plants. A similar study has shown that BSMVVIGS can be used for down regulation of important genes in B. distachyon (Pacak et al., 2010). VIGS is a fast and reliable method for stable knock-down of a desired gene which would produce a phenotype; therefore it could be employed as a quick method for cereal species where stable genetic transformation is required but a very laborious choice (Wege et al., 2007; Ma et al., 2012). To our knowledge, this is the first report on the functional analysis of G-protein on barley plants through BSMVbased VIGS.

In the present study, results showed that silencing caused etiolated phenotypes and also reduced the plant growth in terms of height and leaf area which is important for photosynthetic capacity. Elimination of $\mathrm{G} \alpha$ subunit in cells suppressed the seedling development at 3-leaf stage that an active stage of vegetative growth. These results are consistent with Colaneri et al. (2014), who also reported reduction in shoot growth and early senescence of leaves under salt stress in Arabidopsis plants lacking with heterotrimeric protein. $\mathrm{G} \alpha$ subunit required for cell division under stress and the $\mathrm{G} \alpha$-null alleles caused decline in cell division in the leaf-length in Arabidopsis and maize (Ullah et al., 2001; Bommert et al., 2013). Maintenance of higher leaf area index seems to be a crucial factor leading to an increase in sink potential in maize and pearl millet (Khanna-Chopra and Maheswari, 1998; Vijayalakshmi et al., 2012). These results revealed that G-protein is necessary for plant growth and are in agreement with the earlier studies which reported that heterotrimeric G-proteins played diverse roles in germination, stomatal aperture regulation, growth and development under normal and various stress conditions (Pandey and Assmann, 2004; Joo et al., 2005; Melotto et al., 2006; Pandey et al., 2006; Wang et al., 2007; Fan et al., 2008; Zhang et al., 2008).

\section{CONCLUSION}

We have established a construct carrying Ga subunit for obtaining knockout barley plants efficiently for further investigations. Silencing of $\mathrm{G} \alpha$ subunit in barley was shown by both phenotypic and genotypic analyses. Our results suggest that silencing of $\mathrm{G} \alpha$ subunit produces etiolated plants with reduced growth which is an indication of suppressed photosynthetic activity in barley.

\section{ACKNOWLEDGMENTS}

This work was supported by Scientific Research Projects Coordination Unit of Istanbul University, project number BAP 4712 and postdoctoral TUBITAK fellowship to MQS. Authors thank to Dr. S.R. Scofield for providing BSMV vectors and Dr. Semra Hasancebi for valuable suggestions in cloning studies.

\section{LITERATURE CITED}

Assmann, S.M. 2002. Heterotrimeric and unconventional GTP binding proteins in plant cell signaling. Plant Cell 14:355373.

Babu, R.C., J. Zhang, A. Blum, D.T. H. Ho, R. Wu and H.T. Nguyen. 2004. HVA1, a LEA gene from barley confers dehydration tolerance in transgenic rice (Oryza sativa L.) via cell membrane protection. Plant Sci 166:855-862

Bommert, P., B.I. Je, A. Goldshmidt and D. Jackson. 2013. The maize Galph gene COMPACT PLANT2 functions in CLAVATA signalling to control shoot meristem size. Nature 502:555-558.

Burch-Smith, T.M., J.C. Anderson, G.B. Martin and SP DineshKumar. 2004. Applications and advantages of virus-induced gene silencing for gene function studies in plants. Plant J. 39: 734-746.

Cakir, C., M.E. Gillespie and S.R. Scofield. 2010. Rapid determination of gene function by virus-induced gene silencing in wheat and barley. Crop Sci. 50:77-84.

Chakravorty, D., Y. Trusov, W. Zhang, B.R. Acharya, M.B. Sheahan, D.W. McCurdy, S.M. Assmann and J.R. Botella. 2011. An atypical heterotrimeric G-protein $\gamma$-subunit is involved in guard cell K-channel regulation and morphological development in Arabidopsis thaliana. Plant J. 67:840-851.

Colaneri, A. C., T.O. Meral, J.P. Huang and A.M. Jones. 2014. Growth attenuation under saline stress is mediated by the heterotrimeric G protein complex. BMC Plant Biol. 14:129.

Fan, L.M., W. Zhang, J.G. Chen, J.P. Taylor, A.M. Jones and S.M. Assmann. 2008. Abscisic acid regulation of guard-cell $\mathrm{K}^{+}$and anion channels in $\mathrm{Gb}^{-}$and RGS-deficient Arabidopsis lines. Proc. Natl. Acad. Sci. USA 105:84768481.

Faralli, M., C. Lektemur, D. Rosellini, F. Gürel. 2015. Effects of heat shock on salinity tolerance in barley (Hordeum vulgare L.): plant growth and stress-related gene transcription. Biologia Plantarum . 59(3):537-546.

Holzberg, S., P. Brosio, C. Gross and G.P. Pogue. 2002. Barley stripe mosaic virus-induced gene silencing in a monocot plant. Plant J. 30:315-327.

Hu, P., Y. Meng and R.P. Wise. 2009. Functional contribution of chorismate synthase, anthranilate synthase, and chorismate mutase to penetration resistance in barley-powdery mildew interactions. Mol. Plant-Microbe Interact. 22:311-320. 
Huang, X., Q. Qian, Z. Liu, H. Sun, S. He, D. Luo, G. Xia, C. $\mathrm{Chu}, \mathrm{J} . \mathrm{Li}$ and $\mathrm{X}$. Fu. 2009. Natural variation at the DEPl locus enhances grain yield in rice. Nat. Genet. 41:494-497.

Huang, C.J., Y.J. Qian, Z.H. Li and X.P. Zhou. 2012. Virusinduced gene silencing and its application in plant functional genomics. Sci. China Life Sci. 55:99-108.

Hurowitz, E.H., J.M. Melnyk, Y.J. Chen, H. Kouros-Mehr, M.I. Simon and H. Shizuya. 2000. Genomic characterization of the human heterotrimeric $\mathrm{G}$ protein alpha, beta, and gamma subunit genes. DNA Res. 7:111-120.

Jackson, A.O., H.S. Lim, J. Bragg, U. Ganesan and M.Y. Lee. 2009. Hordeivirus replication, movement, and pathogenesis. Annu. Rev. Phytopathol. 47:385-422.

Jamaux, I., A. Steinmetz and E. Belhassen. 1997. Looking for molecular and physiological markers of osmotic adjustment in sunflower. New Phytol. 137:117-127.

Joo, J.H., S.Y. Wang, J.G. Chen, A.M. Jones and N.V. Fedoroff. 2005. Different signaling and cell death roles of heterotrimeric $\mathrm{G}$ protein $\alpha$ and $\beta$ subunits in the Arabidopsis oxidative stress response to ozone. Plant Cell. 17:957-970.

Khanna-Chopra, R. and M. Maheswari. 1998. Effect of altering source availability on expression of sink capacity in a maize hybrid and its parents. Europ. J. Agron. 9:101-107.

Kocheva, K.V., G.I. Georgiev and V.K Kochev. 2014. An improvement of the diffusion model for assessment of drought stress in plant tissues. Physiol. Plant. 150: 88-94.

Ma, M., Y. Yan, L. Hunag, M.S. Chen and H.X. Zhao. 2012. Virus-induced gene-silencing in wheat spikes and grains and its application in functional analysis of HMW-GS-encoding genes. BMC Plant Biol. 12:141.

Melotto, M., W. Underwood, J. Koczan, K. Nomura and S.Y. He. 2006. Plant stomata function in innate immunity against bacterial invasion. Cell 126: 969-980.

Meng, Y., M.J. Moscou and R.P. Wise. 2009. Blufensin1 negatively impacts basal defense in response to barley powdery mildew. Plant Physiol. 149:271-285.

Nadeau, J.A. 2009. Stomatal development: new signals and fate determinants. Curr. Opin. Plant Biol. 12:29-35.

Nilson, S.E and S.M. Assmann. 2010. Heterotrimeric G proteins regulate reproductive trait plasticity in response to water availability. New Phytologist 185:734-746.

Pacak, A., K. Geisler, B. Jorgensen, M. Barciszewska-Pacak, L. Nilsson, T.H. Nielsen, J. Elisabeth, G. Mette, J. Iver and M. Albrechtsen. 2010. Investigations of barley stripe mosaic virus as a gene silencing vector in barley roots and in Brachypodium distachyon and oat. Plant Methods 6:26.

Pandey, S. and S.M. Assmann. 2004. The Arabidopsis putative $\mathrm{G}$ protein-coupled receptor GCR1 interacts with the G protein a subunit GPA1 and regulates abscisic acid signaling. Plant Cell 16:1616-1632.

Pandey, S., J.G. Chen, A.M. Jones and S.M. Assmann. 2006. Gprotein complex mutants are hypersensitive to abscisic acid regulation of germination and postgermination development. Plant Physiol. 141:243-256.

Perfus-Barbeoch, L., A.M. Jones and S.M. Assmann. 2004. Plant heterotrimeric $\mathrm{G}$ protein function: insights from Arabidopsis and rice mutants. Curr. Opin. Plant Biol. 7:719-731.

Scofield, S.R., L. Huang, A.S. Brandt and B.S. Gill. 2005. Development of a virus induced gene-silencing system for hexaploid wheat and its use in functional analysis of the Lr21-mediated leaf rust resistance pathway. Plant Physiol. 138: $2165-2173$.

Scofield, S.R. and R.S. Nelson. 2009. Resources for virusinduced gene silencing in the grasses. Plant Physiol. 149:152-157.

Tai, Y.S., J. Bragg and M.C. Edwards. 2005. Virus vector for gene silencing in wheat. Biotechniques 39:310-314.

Ullah, H., J.G. Chen, J.C. Young, K.H. Im, M.R. Sussman and A.M. Jones. 2001. Modulation of cell proliferation by heterotrimeric G protein in Arabidopsis. Science 292:20662069.

Urano, D., A. Colaneri and A.M. Jones. 2014. G $\alpha$ modulates salt-induced cellular senescence and cell division in rice and maize. J. Exp. Bot. 65:6553-6561.

Vijayalakshmi, T., Y. Varalaxmi, S. Jainender, S.K. Yadav, M. Vanaja, N. Jyothilakshmi and M. Maheswari. 2012. Physiological and biochemical basis of water-deficit stress tolerance in pearl millet hybrid and parents. Am. J. Plant Sci. 3:1730-1740.

Wang, S., S. Narendra and N. Fedoroff. 2007. Heterotrimeric G protein signaling in the Arabidopsis unfolded protein response. Proc. Natl. Acad. Sci. USA 104: 3817-3822.

Wang, R.S., S. Pandey, S. Li, T.E. Gookin, Z. Zhao, R. Albert and S.M. Assmann. 2011. Common and unique elements of the ABA regulated transcriptome of Arabidopsis guard cells. BMC Genomics 12:216.

Wege, S.1., A. Scholz, S. Gleissberg, A. Becker. 2007. Highly efficient virus-induced gene silencing (VIGS) in California poppy (Eschscholzia californica): an evaluation of VIGS as a strategy to obtain functional data from non-model plants. Ann. Bot. 100:641-649.

Wu, W.H and S.M. Assmann. 1994. A membrane-delimited pathway of G-protein regulation of the guard-cell inward $\mathrm{K}^{+}$ channel. Proc. Natl. Acad. Sci. USA 91:6310-4.

Yuan, C., C. Li, L. Yan, A.O. Jackson, Z. Liu, C.G. Han, J.L. Yu, and D.W. Li. 2011. A high throughput barley stripe mosaic virus vector for virus induced gene silencing in monocots and dicots. PLoS ONE 6(10): e26468.

Zhang, L., G. Hu, Y. Cheng and J. Huang. 2008. Heterotrimeric $\mathrm{G}$ protein $\alpha$ and $\beta$ subunits antagonistically modulate stomatal density in Arabidopsis thaliana. Dev. Biol. 324: $68-75$. 